\title{
The 38.8 kDa Pili Subunit Hemaglutinin Protein of Acinetobacter baumannii is an Adhesin Protein that can activate s-IgA Production
}

\author{
Heriyannis Homenta ${ }^{1}$, Sumarno Reto Prawiro ${ }^{2}$, Teguh W Sardjono ${ }^{3}$, \\ Noorhamdani $\mathrm{AS}^{2}$ \\ ${ }^{1}$ Department of Microbiology, Faculty of Medicine, University of Sam Ratulangi, Manado \\ ${ }^{2}$ Department of Microbiology, Faculty of Medicine, University of Brawijaya, Malang \\ ${ }^{3}$ Department of Parasitology, Faculty of Medicine, University of Brawijaya, Malang
}

\begin{abstract}
Acinetobacter baumannii (A. baumannii) is a pathogenic bacterium that can cause nosocomial infection in hospitalized patients with many kinds of manifestations. All bacterial infection is initiated by adhesion of bacterium to host cells through certain virulence factor which are called adhesin proteins. The purposes of this study were to isolate the pili subunit hemagglutinin (HA) protein of A. baumannii and to prove whether it functioned as adhesin protein and could activate the production of s-IgA. Isolation of pili subunit protein, was done using SDS-PAGE to get the molecular weight $(M W)$ of pili subunit protein and then hemagglutinated. Adhesion test was conducted using pili subunit HA protein which had the highest titer of hemagglutination test, then coated on enterocyte cells of mice at the doses of $400 \mu \mathrm{g}, 200 \mu \mathrm{g}, 100 \mu \mathrm{g}, 50 \mu \mathrm{g}, 25$ $\mu \mathrm{g}, 12.5 \mu \mathrm{g}, 0 \mu \mathrm{g}$ (control), respectively. ANOVA analysis results of dose response method from pili subunit HA protein of A. baumannii showed a significant difference of the index among treatment doses $(p=0.000)$. It can be seen that lower dose of pili subunit HA protein with $M W$ of $38.8 \mathrm{kDa}$ of A. baumannii could increase adhesion index. The $38.8 \mathrm{kDa}$ pili subunit HA protein had significant influence on the adhesion index $(r=-$ $0.729, p=0.000, R$ square $=0.532, p=0.000$ ). Measurements of s-IgA concentration using ELISA method. There were differences in the number of s-IgA by ELISA test based on the treatment given to the value of $p=$ 0.027 ( 2 <.05; ANOVA), the number of s-IgA in treatment group I differed significantly from the number of $s$ IgA in group III ( $p=0.039$; Tukey test). It can be concluded that the $38.8 \mathrm{kDa}$ pili subunit HA protein of A. baumannii is an adhesin protein and can activate the production of $s-\operatorname{IgA}$.
\end{abstract}

Keywords: Acinetobacter baumannii, pili, hemagglutinin, adhesin protein, s-IgA.

\section{Introduction}

A. baumannii is a gram-negative bacterium, rod-shaped with a size of 2.5 micron during the growth phase and becomes shorter and rounded at the stationary phase. These bacteria live in pairs or groups, aerobics, nonfermenter, positive catalase, negative oxidase that are widespread in soil and water, and can thrive on skin, in mucous membranes, secretions and hospital environment $[1,2,3,4]$. A. baumannii is a pathogenic bacterium that can cause nosocomial infection in hospitalized patients with many kinds of manifestations such as pneumonia, eye, surgical wound or burns, skin, and urinary tract infections, also bacteremia and septicemia $[3,4,5]$.

The process of bacterial is specific, but generally initiated by adhesion of bacterial cell to host cell using certain protein which are called adhesin proteins. The adhesin proteins are differ among each bacterium to others [6,7]. Braun and Vidotto (2004) found that bacteria A. baumannii can agglutinate human erythrocytes AB group, and it's capable of adhesing on polysteryn suspected mediated by fimbriae (pili) of A. baumannii [8]. Gohl et al. (2006) found that the pili of Acinetobacter sp. BD413 strain with a MW of $16 \mathrm{kDa}$ functions as an adhesin protein for adhesion on biotic and abiotic surfaces [9]. Sumarno (2011) found that bacteria V. cholera had adhesin molecules of pili subunit protein with a MW of $37,8 \mathrm{kDa}$ [10].

Choi et al. (2008) found that the bacterial molecule of A. baumannii directly responsible for the death of host cells. Among the various molecules of the bacteria, outer membrane protein A from A. baumannii (AbOmpA) with a MW of $38 \mathrm{kDa}$ was identified as virulence factor (adhesin) that potential to induce host cell death through both mitochondria and nucleus $[11,12,13]$. The outer membrane protein (OMP) with MW of 38 $\mathrm{kDa}$ activated dendritic cells, which cause CD4+ $\mathrm{T}$ cell differentiation into Th1 phenotype [14]. Luo et al. (2012) also found that recombinant OmpA can activate humoral immunity, namely $\operatorname{IgG}$ [15].

Bacteria A. baumannii has pili with a size of 1-3 $\mu \mathrm{m}, 2-8 \mathrm{~nm}$ in diameter and composed of pili subunits protein called fimbrins or pilins. Pili played important roles in adhesion to inert or living surface, and formation of bacterial biofilm that had been recognized as an important cause of human infections [16]. 
Until now, there is no study proved that the pili of A. baumannii has hemagglutinin protein is an adhesin protein and immunogenic. The purpose of this study was to isolate the pili subunit hemagglutinin protein of A. baumannii, and to prove that it is an adhesin protein, which can activate s-IgA production.

\section{Isolation and identification bacteria $A$. baumannii.}

\section{Materials And Methods}

Clinical specimens used to obtain pili protein bacteria A. baumannii collected from the urine of urinary tract-infected patients (UTI), sputum, and pus from hospitalized patients which sent to Microbiology Laboratory, General hospital of dr. Saiful Anwar, Malang from January to February 2013. Identification of bacteria A. baumannii using microbact system, according to the instructions of Oxoid Microbact Identification Kits. Specimens with single infection of A. baumannii were isolated and treated with hemagglutanation test, until getting a sample which has the highest HA titer for further steps of research.

\section{Culture A. baumannii.}

Bacteria A. baumannii were culture with method from Ehara [17].

Isolation method of $A$. baumannii pili.

Isolation of A. baumannii pili was referred to Sumarno [18].

Sodium dodecyl sulfate - polyacrylamide gel electrophoresis (SDS-PAGE).

Monitoring the molecular weight (MW) by SDS-PAGE was done by applying Laemmli method [19].

Method of Isolation of pili subunit protein of $A$. baumannii.

Research method referred to Sumarno [8].

\section{Hemagglutination test.}

Procedure of hemagglutination test used from Hanne and Findkelstain [20].

Isolation of mice enterocytes.

Isolation of mice enterocytes used Weiser method taken from Nagayama [21].

Adhesion test to mice enterocytes.

Procedure of adhesion test bacteria A. baumannii to mice enterocytes adapted from Nagayama [21].

Gram staining.

The smear was stained by Gram, to see the big picture and the description of enterocytes morphology and $A$. baumannii adhesion on enterocytes cell [22].

Method of calculating the adhesion index of bacteria to the mice enterocytes.

The adhesion index representing the average number of bacteria per cell was determined by examining 100 cells. The adhesion index was calculated by microscope under oil immersion with $1000 \mathrm{x}$ magnification [23].

\section{Immunization.}

In this experimental research using male mice of the species mus musculus outbred Balb/C were aged 6-8 weeks, as many as 15 tails mice of the Laboratory of Parasitology, Faculty of Medicine, University of Brawijaya. The mice outbred Balb/C is divided into three treatment groups, each group as much as 5 mices. The experimental research had agreement about ethical clearance from The Ethical Committee Medical Research Faculty of Medicine, University of Brawijaya.

Immunizations were given to Group I: obtained immunization with pili subunit adhesin protein with MW of $38.8 \mathrm{kDa}$ A. baumannii $100 \mu \mathrm{g} / 100 \mu \mathrm{l}+\mathrm{ISCOM} 12 \mu \mathrm{g} / 25 \mu \mathrm{l}$ (under the guidance of ABISCO of ISCONOVA); group II: obtained immunization with pili subunit adhesin protein MW of $38.8 \mathrm{kDa}$ A. baumannii $100 \mu \mathrm{g} / 100 \mu \mathrm{l}$; and group III: as control with PBS $100 \mu$ l. Immunizations were given on days 0,7 and 28 orally. On the day 35, the mice were killed to examined the s-IgA concentrations using ELISA method [24].

\section{Preparation of Mucus.}

Preparation of mucus was carried out as follows: intestinal pieces were washed with cold PBS. Then the intestine was opened so that the visible part of the small intestine mucosa exposed. Layer of mucus was collected by scraping longitudinally with spatel and placed in tubes containing sterile PBS and protease 
inhibitors. The suspension was shaken, then centrifuged at $12,000 \mathrm{rpm}$ in $4^{\circ} \mathrm{C}$ for $10 \mathrm{~min}$. The supernatant was taken to perform purification of s-IgA. The supernatant was resuspended with PBS after that dialysis was performed with the use of PBS and used as a sample for examination of s-IgA by ELISA method.

\section{Examination of s-IgA by ELISA method.}

s-IgA examination was done by ELISA method using mouse s-IgA ELISA kit from R and D.

\section{Data Analysis.}

Statistical analysis used ANOVA. Results of research was significant when $p<0.05$ was achieved. Post hoc analysis was then performed with the Tukey test if there were significant differences.

\section{Results}

The A. baumannii isolate derived from 521 of urine, 538 of sputum, and 253 of pus samples which had single infection of $A$. baumannii and fulfilling inclusion criteria.

There were eight samples consists of two samples of urine, two samples of pus, and four samples of sputum treated with hemagglutination test on whole cells to determine the samples that had the highest titer, and used for further steps of research. The sixth sample from pus that had the highest titer on dilution 1/16, and the results can be seen in Figure 1.

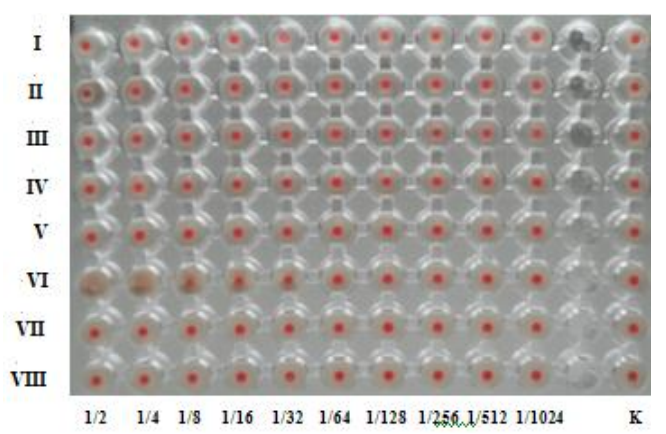

Figure 1. Results of hemagglutination test to whole cells of Acb.

Description: sample from urine (I,IV), sample from sputum (II,V,VII,VIII), and sample from pus (III,VI)

$$
\text { K: erythrocytes and PBS } 7.4
$$

Sixth samples that had the highest titers in hemagglutination test were planted on TCG-BHI medium for 24 hours, then harvested for cutting of pili using bacterial pili cutter. Pieces of pili were composed from pieces of the first to fourth, and the residual of bacteria of the fourth pieces were performed with SDS-PAGE. Results of electrophoresis as in Figure 2.

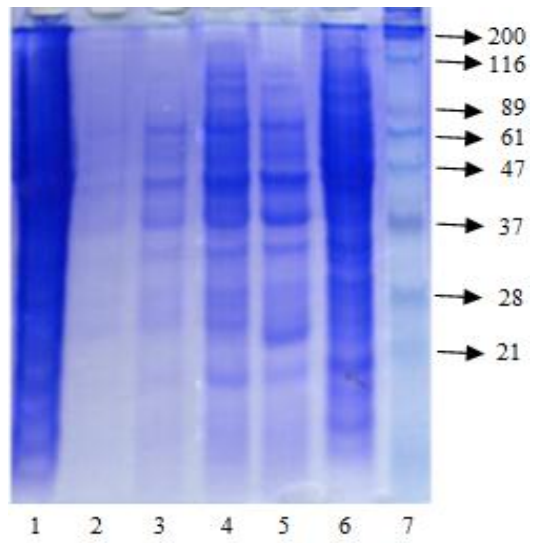

Figure 2.Results of electrophoresis from pieces of pili with SDS-PAGE (12.5\%) method.

Description: well 1: The residual of bacteria of the fourth pieces, well 2: The fourth piece,

well 3: The third piece, well 4: The second piece, well 5: The first piece,

well 6: The whole cells of bacteria, well 7: Marker (Nacalai tesque, product no.02525)

Pieces of A. baumannii pili were treated with the hemagglutination test, whole cell, first, second, third, fourth pili pieces, and the residual of the pili fourth piece. Hemagglutination test using erythrocytes from human with O blood group and mice. The results are given in Figure 3, and these showed that the second piece of the pili had the highest titer 1/16. 


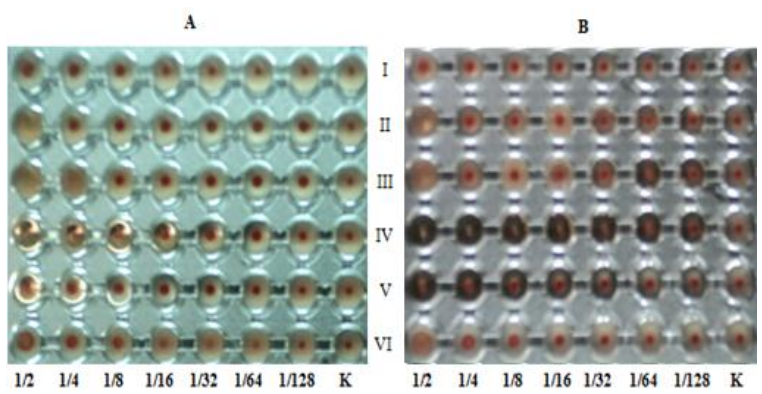

Figure 3.Result of the hemagglutination test from pili pieces.

Description: A: Human erythrocytes of O bloodgroup, B: Erythrocytes of mice.

I: The whole cells of bacteria, II: The first pili piece, III: The second pili piece, IV: The third pili piece,

V: The fourthpili piece, VI: The residual of bacteria of the fourth pieces, K: erythrocytes and PBS 7.4.

Figure 2. showed that a good expression of the protein band is the second piece, and the Figure 3 showed that the second piece of the pili had the highest titer 1/16 both on erythrocytes from human with $\mathrm{O}$ blood group and mice, hence the second piece of pili was performed the SDS-PAGE showing the presence of several prominent proteins, a protein with a MW of $68 \mathrm{kDa}, 44.4 \mathrm{kDa}, 38.8 \mathrm{kDa}$, and $36.7 \mathrm{kDa}$, respectively, as shown in Figure 4.

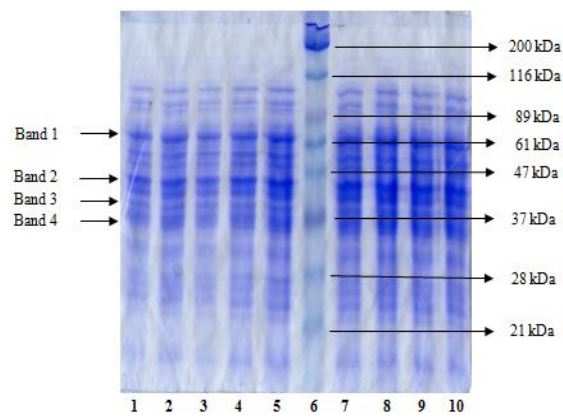

Figure 4.Profil of pili subunit protein from the second piece of bacterial pili of $A$. baumannii.

Description: 1-5, 7-10: The second piece of pili, 6: Marker (Nacalai tesque, product no.02525)

The choiced of four bands were electroeluted, dialysed, and hemagglutinated. The results of hemagglutination test for fourth of pieces bands can agglutination erythrocytes, but it was found that the third piece band, $38.8 \mathrm{kDa}$, had the highest titer 1/128 (line A-III) to human erythrocytes of O blood group and the titer 1/8 to erythrocytes of mice (line B-III). The result could be seen in Figure 5.

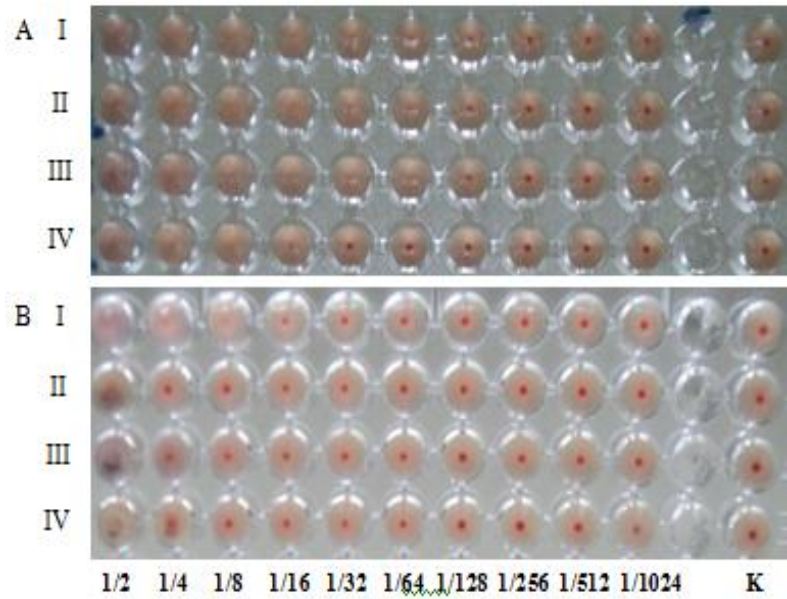

Figure 5. Result of hemagglutination test from the four bands of pili subunit $\mathrm{HA}$ protein.

Description: A: Human erythrocytes of O blood group, B: Erythrocytes of mice.

I: The first band with MW of $68 \mathrm{kDa}$, II: The second band with MW of $44.4 \mathrm{kDa}$, III: The third band with MW of $38.8 \mathrm{kDa}$, IV: The fourth band with MW of $36.7 \mathrm{kDa}$, K: erythrocytes and PBS 7.4

The third piece band of pili subunit protein, MW $38.8 \mathrm{kDa}$ had the highest titer was continued with adhesion test. The results were given in Figure 6 A to G. 


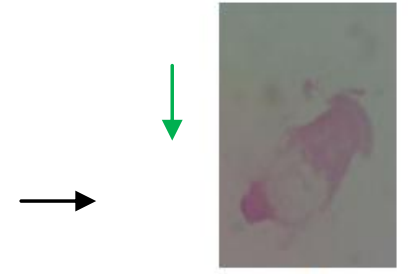

A

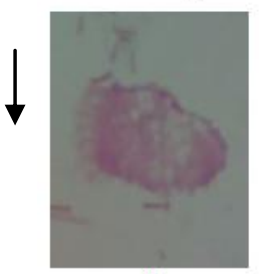

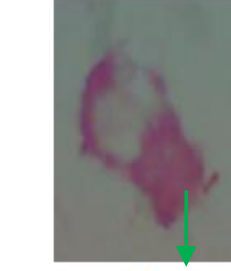

B

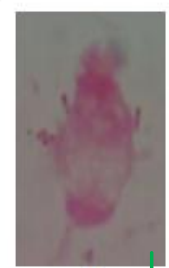

F
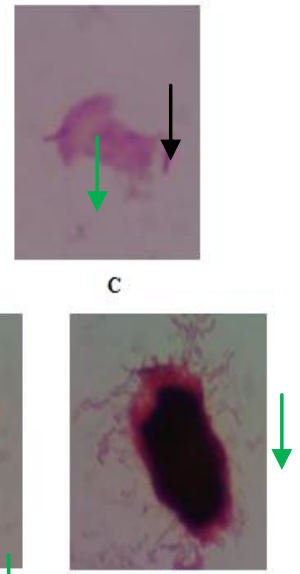

Figure 6. The result of attachment of $A$. baumannii to enterocytes after coated with pili subunit protein of $38.8 \mathrm{kDa}$ at dose of $400 \mu \mathrm{g}(\mathrm{A}), 200 \mu \mathrm{g}(\mathrm{B}), 100 \mu \mathrm{g}(\mathrm{C}), 50 \mu \mathrm{g}(\mathrm{D}), 25 \mu \mathrm{g}(\mathrm{E}), 12.5 \mu \mathrm{g}(\mathrm{F})$,

Description: Photomicroscope Olympus with $1000 \mathrm{X}$ magnification. There wetedifferences number of A.baunanivi attached to enterocyte after coated with pili subunit protein of $38.8 \mathrm{kDa}(\mathrm{A}-\mathrm{F})$ compared with control $(\mathrm{G})$. The green arrow: bacteria of

A. baumannii, and the black arrow: enterocyte of mice.

The adhesion index (AI) is the numbers of bacteria which attach to enterocytes. The AI was calculated by counting the numbers of bacteria attach to 100 enterocytes, andas shown in Table 1.

Tabel 1. The result of statistical analysis of the effect various dose of pili subunit protein with MW of 38.8 kDa to the AI

\begin{tabular}{ccccc}
\hline Code & Dose of protein & n & Mean \pm SD & p-value \\
\hline A & $400 \mu \mathrm{g}$ & 3 & $78.33 \pm 1.53^{\mathrm{a}}$ & \\
B & $200 \mu \mathrm{g}$ & 3 & $102.00 \pm 1.00^{\mathrm{b}}$ & \\
$\mathbf{C}$ & $100 \mu \mathrm{g}$ & 3 & $143.67 \pm 1.53^{\mathrm{c}}$ & \\
$\mathbf{D}$ & $50 \mu \mathrm{g}$ & 3 & $193.33 \pm 3.51^{\mathrm{d}}$ & 0.000 \\
E & $25 \mu \mathrm{g}$ & 3 & $293.33 \pm 2.08^{\mathrm{e}}$ & \\
F & $12,5 \mu \mathrm{g}$ & 3 & $405.00 \pm 1.00^{\mathrm{f}}$ & \\
G & $0 \mu \mathrm{g}($ Kontrol) & 3 & $560.33 \pm 2.08^{\mathrm{g}}$ & \\
\hline
\end{tabular}

Note: different notations at each Mean \pm SD value meant that there were significantly different $(\mathrm{p}<0.05)$

The results above showed that pili subunit protein with MW of $38.8 \mathrm{kDa}$ were the hemagglutinin protein and adhesin protein. It was used as antigens to the experimental study to prove that it can activate s-IgA production. The results of the s-IgA concentrations showed that group I had amount of $4.77 \mu \mathrm{g} / \mathrm{ml}$, group II had amount of $4.53 \mu \mathrm{g} / \mathrm{ml}$, and group III had amount of $4.51 \mu \mathrm{g} / \mathrm{ml}$, respectively (figure 7).

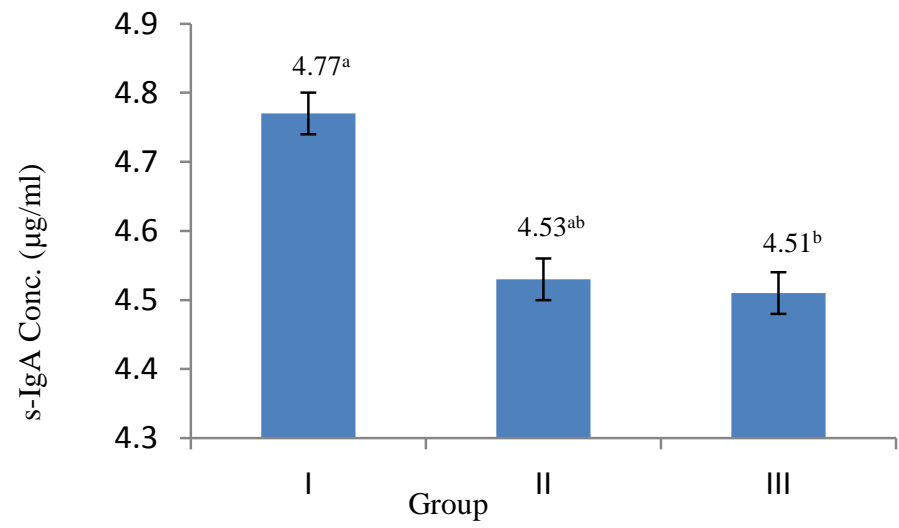

Figure 7. The results of $s-\operatorname{IgA}$ concentrations. 
Note: different notations meant that there were significantly different $(\mathrm{p}<0.05)$, and the same notations meant were no significantly different $(\mathrm{p}>0.05)$.

\section{Discussion}

Selected samples of $A$. baumannii collected from urine, pus and sputum were treated with hemagglutination test using human erythrocytes of $\mathrm{O}, \mathrm{A}, \mathrm{B}$, and $\mathrm{AB}$ blood groups and mice on the whole cells. Hemagglutination test is a method to determine the titer of hemagglutinin protein of bacteria A. baumannii which could agglutinate erythrocytes [21]. The results showed that the sixth samples could agglutinate human erythrocytes of $\mathrm{O}$ blood group and mice erythrocytes. The highest titer of hemagglutination test was selected for bacterial samples and the results can see in Figure 1. From this result, it can be assumed that the sixth sample of bacteria A. baumannii is pathogen nosocomial bacteria, which can colonize and infect to the host.

The results above, showed that the human erythrocyte of $\mathrm{O}$ blood group has a suitable and complementary receptors with bacterial adhesin protein A. baumannii, compared with the human erythrocytes of blood group of $\mathrm{A}, \mathrm{B}$, and $\mathrm{AB}$. It can be concluded that human erythrocytes of $\mathrm{O}$ blood group are more susceptible to bacterial infections of A. baumannii than blood group of A, B, and AB. Noorhamdani (2005) found the bacteria of $A$. baumannii has the F16 fimbria proteins that could agglutinate human erythrocytes of $\mathrm{O}$ blood group and mice erythrocytes, but did not agglutinate erythrocytes rat, guinea pig, sheep, human of A, B, and AB blood group [25]. Sumarno (2011) found the bacteria of $V$. cholerae 01M094V strain that could agglutinate human erythrocytes of $\mathrm{O}$ blood group and mice erythrocytes, but did not agglutinate erythrocytes guinea pig, human of $\mathrm{A}, \mathrm{B}$, and $\mathrm{AB}$ blood group [8].

Samples of the highest titer had been used for further study, in which the bacteria of $A$. baumannii were cultured in biphasic media TCG-BHI for 48 hours in order to grow the bacterial, and then harvested. The bacteria were cut with pili bacterial cutter until the supernatant of the bacterial pili pieces was already clear.

The results of cutting bacterial pili of A. baumannii consisted from pili of the first, second, third, fourth pieces, and the residual of the pellets of the fourth pieces treated with SDS-PAGE. Hemagglutination test showed that the second piece of the pili had the consistent bands expression and highest titer (Figure 2 and Figure 3). SDS-PAGE is method to gained the molecular weight and consistent bands expression of pili subunit protein. Bacteria having a structure that functions to attach to hosts are pili or fimbria composed of a protein called pilin and afimbria, a protein found on the surface of bacterial cells (OMP) [6]. Moreover, the second piece of pili which was performed the SDS-PAGE showing the presence of several prominent proteins, such as proteins with MW of $68 \mathrm{kDa}, 44.4 \mathrm{kDa}, 38.8 \mathrm{kDa}$, and $36.7 \mathrm{kDa}$, respectively, as shown in Figure 4. The fourth of protein bands piece showed a dominant and consistent, so can be assumed that it has more and better than the other pieces of bands. Research conducted by Sumarno found the molecular weight profile of the protein pili subunits from both Salmonella thypi and Vibrio cholerae [8,18].

The fourth of bands were electroeluted, dialysed, and then hemagglutinated. The results of hemagglutination test for fourth of pieces bands could agglutinate erythrocytes, but it was found that the third piece band, $38.8 \mathrm{kDa}$, had the highest titer to human erythrocytes of $\mathrm{O}$ blood group and could be seen in Figure 5. It's mean that pili subunit protein with MW of $38.8 \mathrm{kDa}$ is a hemagglutinin (HA) protein. Adhesin protein in some bacterial form of protein that can agglutinate erythrocytes known as hemagglutinin protein [21].

Adhesion is the attachment process of bacteria on the surface of host cells. Bacterial cells that enter to the host body should conduct initial adhesion as the mechanism of infection, without adhesion the bacteria will be removed from the body through mucous fluids or body fluids that pass through the surface of the host cells. Hemagglutinin protein is identical with the adhesin protein as cell surface receptors that are responsible for cell interactions or interactions between cells and the extracellular matrix. The process of bacterial infection begins with adhesion of a bacterial cell to host cells through either adhesin virulence factors derived from pili and nonpili, for example, outer membrane proteins. The adhesion of bacterial cell to the host cells is specific [6,7]. In this study, the third band of pili subunit protein of $A$. baumannii was continued with adhesion test obtained the highest titer, it was $38.8 \mathrm{kDa}$. The results given in Figure 6 and Table 1 showed that the larger the dose of protein coated, the less bacteria attached to the enterocytes of mice. It meant that the more receptors are saturated by the hemagglutinin protein the less bacteria that attach to the receptors. Adhesion of bacteria on surface of eucariota cells could inhibit with adhesin protein had isolated [26].

ANOVA analysis results of dose response method from pili subunit HA protein with MW of $38.8 \mathrm{kDa}$ of $A$. baumannii showed significant differences of the index among treatment doses $(\mathrm{p}=0.000)$. It's means the larger dose of pili subunit HA protein with MW of $38.8 \mathrm{kDa}$ of $A$. baumannii could reduce adhesion index. Pili subunit HA protein with MW of $38.8 \mathrm{kDa}$ had a close relationship and a significant influence on the adhesion index $(r=-0,729, p=0,000, R$ square $=0532, p=0.000)$. Regression test showed that a significant correlation between pili proteins MW of $38.8 \mathrm{kDa}$ and an adhesion index of bacteria A. baumannii in the mice enterocytes. The adhesion and adhesion inhibition tests empirically exhibited that the pili subunit HA protein with MW of 
$38.8 \mathrm{kDa}$ as an adhesin protein. These results are consistent with Sumarno found pili subunit HA protein with MW of $37.8 \mathrm{kDa}$ bacteria of Vibrio cholerae O1M09V as an adhesion protein [8].

$\mathrm{B}$ cells that changed to be IgA plasma cells that had been induced and stimulated by antigen in the germinal center will cause an interaction between B cells, follicular dendritic cells that present antigen to local CD4 T cells and facilitates B cell proliferation, class switch recombinant (CSR), somatic hypermutation and affinity maturation required for efficient humoral immune response [27]. In the plasma cells, IgM changed to be IgA that induced by cytokines, transforming growth factor- $\beta$ (TGF- $\beta$ ) and interlekin-5 (IL-5). The s-IgA in lamina propia that transported across through epithelial cells to luminal surface by an IgA-specific factor receptor. On the luminal surface, the IgA will released from the bound receptor, then it can recognizes to ingested of the microbes and their toxin. The repeated exposure of protein antigen will produce antibodies with increased affinity toward the antigen. This process is called affinity maturation, it can cause the production of antibodies with increase in capacity of binding and neutralizing the microbes and toxins [28].

The experimental study conducted the Elisa test to measure levels of s-IgA. In this study, protein that act as antigen was a pili subunit protein A. baumannii with MW of $38.8 \mathrm{kDa}$, and could be seen in Figure 7 . Immunizations were repeated on days $0,7,28$ to stimulate the production of IgM antibodies to IgA antibodies in plasma cells.

ANOVA showed that the significance value of 0.027 ( $\mathrm{p}<0.05$ ), it found that there are differences in the number of s-IgA concentration based on the treatment given. Then, Tukey test showed that the s-IgA concentration in group I treatment (antigen + iscom) differ significantly from that of the s-IgA concentration in group III treatment (control) $(\mathrm{p}=0.039)$. Results of this experimental study showed that the pili subunit HA protein A. baumannii with MW of $38.8 \mathrm{kDa}$ could activated s-IgA in the treatment to group I and II was higher than the treatment to group III (control). These results are consistent with Czinn which found that there was an increase of s-IgA concentration in gastric of mice after intragastric immunization with killed $\mathrm{H}$. pylori combined with cholerae toxin (CT) [29]. Setyorini et al. (2013) also found an increased in levels of s-IgA in the intestine of mice after oral immunization pili subunit protein $49.8 \mathrm{kDa}$ of bacteria $S$. dysenteriae combined with iscom that compared with the control group [24].

This study concluded that the pili subunit HA protein of A. baumannii with a MW of $38.8 \mathrm{kDa}$ is an adhesin protein and can activate the production of s-IgA.

\section{References}

[1]. Levinson W, and Jawetz E. 2000. Minor Bacterial Pathogens. In: Medical Microbiology and Immunology. 6th Ed. San Francisco: A Lange Medical Book. pp. 156-61.

[2]. Brooks GF, Butel JS, Morse SA. 2004. Pseudomonads, Acinetobacters, dan uncommon Gram-negative Bacteria. In: Jawetz, Melnick, and Adelberg's Medical Microbiology. 23th Ed. San Francisco : A Lange medical Book. pp. 262-68.

[3]. Peleg A.Y, Seifert H, and Paterson D.L. 2008. Acinetobacter baumannii: Emergence of a Successful Pathogen. Clin. Microbiol. 21(3): 538-82.

[4]. Zarrilli R, Crispino M, Bagattini M, Barretta E, Di Popolo A, Triassi M, and Villari P. 2004. Molecular Epidemiology of Sequential Outbreaks of Acinetobacter baumannii in an Intensive Care Unit Shows the Emergence of Carbapenem Resistance. Journal of clinical microbiology. 42(3): 946-53.

[5]. Holmes B and Howard BJ, 1994. Nonfermentative Gram-Negative Bacteria. In: Clinical and Pathogenic Microbiology, 2nd ed. Howard BJ et al (ed.), St. Louis, Washington DC, Toronto: CV Mosby Co, pp.337-64.

[6]. Salyers, A., Whitt, D. 2002. Bacterial Pathogenesis - A molecular approach. 2nd Edition. Washington DC, ASM Press.

[7]. Alam M, Miyoshi S, Tomochika K, Shinoda S, 1997. Vibrio mimicus Attaches to the Intestinal Mucosa by Outer Membrane Hemagglutinins Specific to Polypeptide Moieties of Glycoproteins. Infect Immun, 65: 3662-5.

[8]. Braun, G, M.C. Vidotto, 2004. Evaluation of Adherence, Hemagglutination, and Presence of Genes Codifying for Virulence Factors of Acinetobacter baumannii Causing Urinary Tract Infection. Mem Inst Oswaldo Cruz, Rio de Janeiro. 99(8): 839-44.

[9]. Gohl O, Friedrich A, Hoppert M, Averhoff B. 2006. The Thin Pili of Acinetobacter sp. Strain BD413 Mediate Adhesion to Biotic and Abiotic Surfaces. Appl. Environ. Microbiol. All Rights Reserved. Doi:10.1128/AEM. 72 (2): 1394-401.

[10]. Sumarno R.P., Susanto A., Ismanoe G., Winarsih. 2011. Combinations of protein subunit pili 37,8 kDa V. cholerae with Cholera Toxin Subunit B, V. cholerae can protect come out of the solution in the intestinal mice. J. Pharm. Biomed. Sci. 1: 154-60.

[11]. Choi CH, Lee EY, Lee YC, Park TI, Kim HJ, Hyun SH, Kim SA, Lee SK, Lee JC. 2005. Outer membrane protein 38 of Acinetobacter baumannii localizes to the mitochondria and induces apoptosis of epithelial cells. In: Loehfelm TW, Luke NR, Compagnari AA. 2008. Identification and Characterization of an Acinetobacter baumannii Biofilm-Associated Protein. Journal of bacteriology. 190 (3): 1036-44.

[12]. Choi CH, Lee JS, Lee YC, Park TI, Lee JC. 2008. Acinetobacter baumannii invades epithelial cells and outer membrane protein A mediates interactions with epithelial cells. BMC Microbiology. 8: 1-11.

[13]. Jin JS, Kwon S-O, Moon DC, Gurung M, Lee JH, et al. 2011. Acinetobacter baumannii Secretes Cytotoxic Outer Membrane Protein A via Outer Membrane Vesicles. PLoS ONE. 6(2): e17027. doi:10.1371/journal.pone.0017027.

[14]. Lee JS, Lee JC, Lee CM, Jung ID, Jeong YI, Seong EY, Chung HY, Park YM. 2007. Outer membrane protein A of Acinetobacter baumannii induces differentiation of CD4+ T cells toward a Th1 polarizing phenotype through the activation of dendritic cells. In: Loehfelm TW, Luke NR, Compagnari AA. 2008. Identification and Characterization of an Acinetobacter baumannii BiofilmAssociated Protein. Journal of bacteriology. 190 (3): 1036-44.

[15]. Luo G, Lin L, Ibrahim AS, Baquir B, Pantapalangkoor P, et al. 2012. Active and Passive Immunization Protects against Lethal, Extreme Drug Resistant-Acinetobacter baumannii Infection. PLoS ONE 7(1): e29446. doi:10.1371/journal.pone.0029446.

[16]. Gohl O, Friedrich A, Hoppert M, Averhoff B. 2006. The Thin Pili of Acinetobacter sp. Strain BD413 Mediate Adhesion to Biotic and Abiotic Surfaces. Appl. Environ. Microbiol. 72 (2): 1-9. 
[17]. Ehara, M., Ishibashi, M., Ichinose. Y., Iwanaga, M., Shimotori, S., \& Naito, T. 1987. Purification and partial characterization of fimbriae of Vibrio cholerae O1. Vaccine. 5(4): 283-8.

[18]. Sumarno R.P., Uun Y., Winarsih, Santoso S., Samsul I. 2012. Detection of molecule adhesion subunit pili 48 kDa Salmonella typhi by immunochemistry method using sera patiants suffering from typhoid fever. J. Basic. Appl. Sci. Res. 2: 8527-32.

[19]. Laemli, U.K, 1970. Cleavage of structural proteins during the assembly of the head of bacteriophage T4. Nature. 227: 680-5.

[20]. Hanne, L.F, and Findkelstein, R.A. 1982. Characterization and distribution of the hemagglutinins produced by Vibrio cholerae. Infect. Immun. 36: 209-14.

[21]. Nagayama K, Oguchi T, Arita M, Honda T. 1995. Purification and Characterization of a Cell-Associated Hemagglutinin of Vibrio parahaemolyticus. Infect Immun, 63: 1987-92.

[22]. Forbes BA, Sahm DF, Weissfeld AS. 2007. Bailey \& Scott's Diagnostic Microbiology. 12 ${ }^{\text {th }}$ Ed. Philadelphia, PA, USA : Mosby Inc., an affiliate of Elsevier Inc. ISBN: 13 978-0-323-03065-6.

[23]. Martino PD, Bertin Y, Girardeu JP, Livrelli V, Jolly B, Daefeuille-Michaud A, 1995. Molecular Characterization and Adhesive Properties of CF29K, an Adhesin of Kleibsiella pneumonia Strain Involved in Nosocomial Infection', Infection and Immunity 63: 4336-44.

[24]. Setyorini, D., Utami, YD., Widjayanto, E., Winarsih, S., Noorhamdani, AS.,and Sumarno, RP. 2013. Protectivity of adhesion molecules pili $49,8 \mathrm{kda}$ Shigella dysenteriae conjugated with iscom against bacterial colonization and colonic epithelial cells damage in mice. Int. J. Trop. Med., 8(1): 19-26.

[25]. Noorhamdani. 2005. Protein Fimbria 16 kDa Bakteri Acinetobacter baumannii dari Urine Penderita Infeksi Saluran Kemih Berperan Sebagai Protein Hemaglutinin dan Adhesin. Jurnal Ilmu Kedokteran Brawijaya. 21(1): 44-52.

[26]. Todar K. 2008-2012. Colonization and Invasion by Bacterial Pathogen. Web Review of Todar's Online Textbook of Bacteriology. "The Good, the Bad, and the Deadly". Madison, Wisconsin. p. 1-12.

[27]. Brandtzaeg P. 2010. Update on mucosal immunoglobulin A in gastrointestinal disease. Curr. Opin. Gastroenterol. 26: 554-63.

[28]. Abbas AK., and Lichtman AH. 2011. Basic Immunology: Functions and Disorders of The Immune System. 3rd ed. Philadelphia, London, Toronto: Saunders Co, pp. 23-44, 67-88.

[29]. Czinn SJ., and Nedrud JG. 1991. Oral Immunization against Helicobacter pylori. Infect Immun. July. 59(7): $2359-63$. 